\title{
Morphology and multigene phylogeny reveal a new species and a new record of Rhytidhysteron (Dothideomycetes, Ascomycota) from China
}

\section{De Silva NI ${ }^{1,2,3,4,6}$, Tennakoon $\mathrm{DS}^{5,6,8}$, Thambugala $\mathrm{KM}^{9}$, Karunarathna $\mathrm{SC}^{4,7^{*}}$, Lumyong $S^{2,3,10^{*}}$ and Hyde $\mathrm{KD}^{2,4,6,7,8}$}

\author{
${ }^{1}$ PhD's Degree Program in Biodiversity and Ethnobiology, Department of Biology, Faculty of Science, Chiang Mai \\ University, Chiang Mai, 50200, Thailand \\ ${ }^{2}$ Department of Biology, Faculty of Science, Chiang Mai University, Chiang Mai, 50200 Thailand \\ ${ }^{3}$ Research Center of Microbial Diversity and Sustainable Utilization, Faculty of Science, Chiang Mai University, \\ Chiang Mai, 50200 Thailand \\ ${ }^{4}$ Key Laboratory for Plant Biodiversity and Biogeography of East Asia (KLPB), Kunming Institute of Botany, Chinese \\ Academy of Science, Kunming 650201, Yunnan China \\ ${ }^{5}$ Department of Plant Medicine, National Chiayi University, 300 Syuefu Road, Chiayi City 60004, Taiwan \\ ${ }^{6}$ Center of Excellence in Fungal Research, Mae Fah Luang University, Chiang Rai, 57100, Thailand \\ ${ }^{7}$ World Agro Forestry Centre, East and Central Asia, 132 Lanhei Road, Kunming 650201, Yunnan China \\ ${ }^{8}$ School of Science, Mae Fah Luang University, Chiang Rai, 57100, Thailand \\ ${ }^{9}$ Genetics and Molecular Biology Unit, Faculty of Applied Sciences, University of Sri Jayewardenepura, Gangodawila, \\ Nugegoda, Sri Lanka \\ ${ }^{10}$ Academy of Science, The Royal Society of Thailand, Bangkok, Thailand
}

De Silva NI, Tennakoon DS, Thambugala KM, Karunarathna SC, Lumyong S, Hyde KD 2020 Morphology and multigene phylogeny reveal a new species and a new record of Rhytidhysteron (Dothideomycetes, Ascomycota) from China. Asian Journal of Mycology 3(1), 295-306, Doi 10.5943/ajom/3/1/4

\begin{abstract}
Rhytidhysteron is an ecologically diverse group of Dothideomycetes occurring as endophytes, saprobes and weak pathogens on woody plants in terrestrial and intertidal habitats. During our field surveys in China, we collected Rhytidhysteron species on dead twigs of Magnolia grandiflora and decaying wood of Morus australis. Both morphology and multigene phylogenetic analyses showed one taxon to be a new species, while the other is a new record of Rhytidhysteron thailandicum. Combined LSU, SSU, ITS and tefl sequence data were used for the phylogenetic analyses. Descriptions, micrographs and a phylogenetic tree to show the placement of the two species in Rhytidhysteron (Hysteriaceae) are provided.
\end{abstract}

Key words - 1 new taxon - Hysteriaceae - Hysteriales - Magnolia grandiflora - Morus australis Rhytidhysteron magnoliae

\section{Introduction}

Dothideomycetes comprise a highly diverse range of fungi occurring on various hosts and substrates in different types of ecosystems worldwide (Liu et al. 2017). The class is mainly characterized by asci with two wall layers (bitunicate asci) often with fissitunicate dehiscence (Hyde et al. 2013, Wijayawardene et al. 2017, 2018). Currently, with an estimated $19,000^{+}$species, the Dothideomycetes is considered as the largest class in Ascomycota (Liu et al. 2017, Ariyawansa et al. 2018, Hongsanan et al. 2020). 
Hysteriaceous fungi are a group of Dothideomycetes that are characterized by carbonaceous, semi-immersed to superficial hysterithecioid or apothecioid ascomata, which distinctly navicular in outline, bearing a pronounced, longitudinal slit, running the entire length of the long axis. Asci are bitunicate and ascospores are hyaline to pigmented, one to multi-septate, or muriform (Boehm et al. 2009a, b, Hyde et al. 2013, de Almeida et al. 2014, Thambugala et al. 2016, Kumar et al. 2019). Species of the family are mainly saprobes and rarely weak pathogens on a wide range of woody plants in temperate and tropical regions (Boehm et al. 2009a, b, de Almeida et al. 2014, Thambugala et al. 2016). Molecular analyses place Hysteriaceous fungal taxa in Hysteriaceae, Hysteriales, Pleosporomycetidae and currently, 14 genera are accepted (Boehm et al. 2009a, b, Hyde et al. 2013, Jayasiri et al. 2017, Wijayawardene et al. 2017, 2018).

Rhytidhysteron Speg. is a species-rich genus in Hysteriaceae Chevall. and is characterized by its rather large, conspicuous closed and navicular ascomata, which open by a longitudinal slit that becomes irregularly apothecioid when wet and pigmented, sparsely septate to submuriform ascospores (Boehm et al. 2009b, Thambugala et al. 2016, Soto \& Lucking 2017). Members of Rhytidhysteron have a worldwide distribution and play a vital role as endophytes, saprobes, weak pathogens on woody plants in terrestrial habitats and rarely as human pathogens (Thambugala et al. 2016, Soto \& Lucking 2017, Kumar et al. 2019). Currently, there are 21 epithets listed in Index Fungorum (2020).

The present study reports a novel taxon of Rhytidhysteron on Magnolia grandiflora L. and a new host record of Rhytidhysteron thailandicum Thambug. \& K.D. Hyde on Morus australis Poir. in China.

\section{Materials \& Methods}

Fresh plant specimens were collected from a subtropical rain forest at the Xishuangbanna Tropical Botanical Garden in Yunnan Province and the Dahu Forest, Fanlu Township area, Chiayi, Taiwan region. Fungi were isolated from dead twigs attached to the Magnolia grandiflora and decaying wood of Morus australis. The collections were brought to the laboratory in Ziplock plastic bags and observed with a JNOEC JSZ4 stereomicroscope. Micro-morphological characteristics were examined with an OLYMPUS SZ61 compound microscope and images were recorded with a Canon EOS 600D digital camera mounted on a Nikon ECLIPSE 80i compound microscope. All microscopic measurements were made with the Tarosoft (R) image framework v. 0.9.0.7 and images were further processed with Adobe Photoshop CS3 Extended version. Pure cultures were obtained by single spore isolation as outlined by Chomnunti et al. (2014). Germinating ascospores were transferred aseptically to potato dextrose agar (PDA) and culture characteristics, such as growth rate and colony characteristics, were determined from cultures grown on PDA at room temperature $\left(25^{\circ} \mathrm{C}\right)$ for one week.

The specimens cited in this paper are lodged at the Mae Fah Luang University Herbarium (MFLU), Chiang Rai, Thailand and Kunming Institute of Botany herbarium (HKAS), Kunming, China. The living fungal cultures obtained in this study were deposited at the Kunming Institute of Botany Culture Collection (KUMCC). Faces of Fungi numbers and Index Fungorum numbers were registered as described in Jayasiri et al. (2015) and Index Fungorum (2020), respectively.

\section{DNA extraction, PCR amplification and sequencing}

Isolates of fungi were grown on PDA for one week at $25^{\circ} \mathrm{C}$ under normal light conditions and scraped mycelia were used for DNA extraction. DNA extraction was carried out using a Biospin fungus genomic DNA kit (BioFlux ${ }^{\circledR}$, P.R. China) following the manufacturer's protocol.

PCR amplifications were carried out for the partial 28S large subunits of the nuclear ribosomal RNA genes (LSU) using primer pair LROR and LR5 (Vilgalys \& Hester 1990); the partial 18S small subunit nuclear rDNA (SSU) using primer pair NS1 and NS4 (White et al. 1990); the internal transcribed spacers (ITS) using primer pair ITS5 and ITS4 (White et al. 1990) and the translation elongation factor 1-alpha gene (tefl) using primer pair EF1-983F and EF1-2218R (Rehner 2001). 
Table 1 GenBank accession numbers and culture accession numbers of the taxa included in the present phylogenetic analysis. The newly generated sequences are shown in black bold.

\begin{tabular}{|c|c|c|c|c|c|}
\hline \multirow[t]{2}{*}{ Taxon } & \multirow{2}{*}{$\begin{array}{c}\text { Culture Accession } \\
\text { Number }\end{array}$} & \multicolumn{4}{|c|}{ GenBank Accession Number } \\
\hline & & LSU & SSU & tef1 & ITS \\
\hline Gloniopsis praelonga & CBS 112415 & FJ161173 & FJ161134 & FJ161090 & - \\
\hline Rhytidhysteron bruguierae ${ }^{\mathrm{T}}$ & MFLUCC 18-0398 & MN017833 & MN017901 & MN077056 & - \\
\hline Rhytidhysteron hysterinum & EB 0351 & GU397350 & - & GU397340 & - \\
\hline Rhytidhysteron magnoliae $^{\mathrm{T}}$ & MFLUCC 18-0719 & MN989384 & MN989382 & MN997309 & MN989383 \\
\hline Rhytidhysteron mangrovei ${ }^{\mathrm{T}}$ & MFLUCC 18-1113 & MK357777 & - & MK450030 & MK425188 \\
\hline \multirow{9}{*}{ Rhytidhysteron neorufulum ${ }^{\mathrm{T}}$} & MFLUCC 13-0216 & KU377566 & KU377571 & KU510400 & KU377561 \\
\hline & GKM 361A & GQ221893 & GU296192 & GU349031 & - \\
\hline & HUEFS 192194 & KF914915 & - & - & - \\
\hline & MFLUCC 12-0528 & KJ418117 & KJ418119 & - & KJ418118 \\
\hline & CBS 306.38 & FJ469672 & AF164375 & GU349031 & - \\
\hline & MFLUCC 12-0011 & KJ418109 & KJ418110 & - & KJ206287 \\
\hline & MFLUCC 12-0567 & KJ526126 & KJ546129 & - & KJ546124 \\
\hline & MFLUCC 12-0569 & KJ526128 & KJ546131 & - & KJ546126 \\
\hline & EB 0381 & GU397351 & GU397366 & - & - \\
\hline Rhytidhysteron opuntiae & GKM 1190 & GQ221892 & - & GU397341 & - \\
\hline \multirow[t]{5}{*}{ Rhytidhysteron rufulum ${ }^{\mathrm{T}}$} & MFLUCC 14-0577 & KU377565 & KU377570 & KU510399 & KU377560 \\
\hline & EB 0384 & GU397354 & GU397368 & - & - \\
\hline & EB 0382 & GU397352 & - & - & - \\
\hline & EB 0383 & GU397353 & GU397367 & - & - \\
\hline & MFLUCC 12-0013 & KJ418111 & KJ418113 & - & KJ418112 \\
\hline Rhytidhysteron thailandicum ${ }^{\mathrm{T}}$ & MFLUCC 14-0503 & KU377564 & KU377569 & KU497490 & KU377559 \\
\hline Rhytidhysteron thailandicum & MFLUCC 12-0530 & KJ526125 & KJ546128 & - & KJ546123 \\
\hline Rhytidhysteron thailandicum & MFLU17-0788 & MT093472 & MT093495 & - & MT093733 \\
\hline Rhytidhysteron tectonae $^{\mathrm{T}}$ & MFLUCC 13-0710 & KU764698 & KU712457 & KU872760 & KU144936 \\
\hline
\end{tabular}

${ }^{\mathrm{T}}$ Ex-type strains

The new species and the new record are in black bold.

The final volume of the PCR reaction was $25 \mu$, containing $1 \mu \mathrm{l}$ of DNA template, $1 \mu \mathrm{l}$ of each forward and reward primer, $12.5 \mu \mathrm{l}$ of $2 \times$ Easy Taq PCR SuperMix (a mixture of EasyTaq TM DNA Polymerase, dNTPs, and optimized buffer, Beijing TransGen Biotech Co., Ltd., Beijing, P.R. China) and $9.5 \mu$ of $\mathrm{ddH}_{2} \mathrm{O}$. The PCR amplification was performed for LSU, SSU, ITS and tef1 with an initial denaturing step of $94^{\circ} \mathrm{C}$ for $3 \mathrm{~min}$., followed by 40 amplification cycles of $94^{\circ} \mathrm{C}$ for $45 \mathrm{~s}, 55^{\circ} \mathrm{C}$ for $50 \mathrm{~s}$ and $72^{\circ} \mathrm{C}$ for $1 \mathrm{~min}$. and a final extension step of $72^{\circ} \mathrm{C}$ for $10 \mathrm{~min}$. PCR purification and sequencing of amplified PCR products were carried out at Shanghai Sangon Biological Engineering Technology \& Services Co., Ltd, P.R. China.

\section{Phylogenetic analyses}

The BLAST search engine of the National Centre for Biotechnology Information (NCBI) was used for the preliminary identification of DNA sequences of the new isolates. The LSU, SSU, ITS and tefl sequences of the closely related taxa to our isolates were retrieved from GenBank based on the BLAST search results and recent publications (Thambugala et al. 2016, Doilom et al. 2017, Kumar et al. 2019).

Maximum likelihood trees were generated using RAxMl GUI v. 1.3 (Silvestro \& Michalak 2012) and parameters were set to rapid bootstrapping and the analysis carried out using 1000 replicates and GTRGAMMAI model of nucleotide substitution. An evolutionary model for phylogenetic analyses was selected using MrModeltest v. 3.7 (Posada \& Crandall 1998) under the Akaike Information Criterion (AIC). Bayesian analysis was conducted with MrBayes v. 3.1.2 (Huelsenbeck \& Ronqvist 2001). The GTR $+\mathrm{I}+\mathrm{G}$ model was used for the Bayesian analysis. Parameters of Bayesian analysis in MrBayes v. 3.2; markov chains were run for 1000000 generations and trees were sampled every 100th generations (printfreq $=100$ ) and 10000 trees were obtained. Initial trees were discarded (20\% burn-in value) and remaining trees were used to 
evaluate posterior probabilities (PP) in the majority rule consensus tree. Maximum parsimony analysis was conducted with the heuristic search option in PAUP (Phylogenetic Analysis Using Parsimony) v. 4.0b10 (Swofford 2002). Parameters of maximum parsimony in PAUP were set-up as a heuristic search option, random stepwise addition, and 1000 random sequence additions, with 1000 maxtrees. Gaps were treated as missing data. Tree Length [TL], Consistency Index [CI], Retention Index [RI], Relative Consistency Index [RC] and Homoplasy Index [HI] were calculated for the maximum parsimonious tree. Phylograms were visualized with FigTree v1.4.0 (Rambaut \& Drummond 2008) and annotated in Microsoft Power Point (2010).

\section{Results}

The combined dataset of LSU, SSU, ITS and tefl comprises 23 strains of Rhytidhysteron, and the outgroup taxon Gloniopsis praelonga (Schwein.) Underw. \& Earle (CBS 112415). The maximum likelihood analysis resulted in trees largely with similar topology and clades as in the maximum parsimony and Bayesian analyses. The RAxML analysis yielded the best-scoring tree with a final ML optimization likelihood value of $-8082.346462(\mathrm{ln})$. The maximum parsimonious dataset consisted of 3459 characters, of which 3051 were conserved and 200 variable characters. The parsimony analysis resulted in 1000 equally parsimonious trees and the first tree (length $=568$ steps) with $\mathrm{CI}=0.824, \mathrm{RI}=0.826, \mathrm{RC}=0.681$ and $\mathrm{HI}=0.176$. Estimated base frequencies were as follows; $\mathrm{A}=0.245603, \mathrm{C}=0.236491, \mathrm{G}=0.279689, \mathrm{~T}=0.238217$; substitution rates $\mathrm{AC}=$ $1.477459, \mathrm{AG}=2.203910, \mathrm{AT}=1.391008, \mathrm{CG}=1.013275, \mathrm{CT}=7.644469, \mathrm{GT}=1.000000$; gamma distribution shape parameter $\alpha=0.737155$ (Fig. 1). The new species Rhytidhysteron magnoliae formed a sister clade to $R$. tectonae (MFLUCC13-0710). The new host record of $R$. thailandicum clustered with the type of $R$. thailandicum (MFLUCC 14-0503) with strong statistical support.

Rhytidhysteron magnoliae N.I. de Silva, Lumyong S \& K.D. Hyde, sp. nov.

Fig. 2

Index Fungorum number: IF 557220; Facesoffungi number: FoF 07369

Etymology - The specific epithet reflects the host plant genus Magnolia grandiflora

Holotype - MFLU 18-1021

Saprobic on dead twigs of Magnolia grandiflora. Sexual morph: Hysterothecia 1200-2300 $\mu \mathrm{m}$ long, 430-550 $\mu \mathrm{m}$ high, 540-600 $\mu \mathrm{m}$ diameter $(\overline{\mathrm{x}}=1750 \times 490 \times 570 \mu \mathrm{m}, \mathrm{n}=15)$, apothecioid, with a longitudinal slit, sometimes elliptic or irregular in shape, with lenticular or irregular opening, dark brown to black, coriaceous, solitary to aggregated, semi-immersed to superficial, with striations perpendicular to the long axis, dark brown at the center. Exciple 80-100 $\mu \mathrm{m}$, comprising of two cell layers; outer layer comprising black to dark brown, thick-walled cells of textura angularis, inner layer comprising hyaline, thin-walled, somewhat flattened cells of textura angularis to textura prismatica. Hamathecium comprising 2-3 $\mu \mathrm{m}$ wide, cylindrical to filiform, septate, hyaline pseudoparaphyses, slightly swollen at the apex and enclosed in a gelatinous matrix. Asci (148-)160-200 (-210) × (11-)13-15(-16) $\mu \mathrm{m}(\overline{\mathrm{x}}=176 \times 14 \mu \mathrm{m}, \mathrm{n}=30), 8$-spored, bitunicate, fissitunicate, clavate to cylindrical, with a short pedicel. Ascospores $(25-) 28-30(-32) \times(8-) 10$ $11(-12) \mu \mathrm{m}(\overline{\mathrm{x}}=29 \times 10 \mu \mathrm{m}, \mathrm{n}=30)$, uniseriate, slightly overlapping, pale brown to dark brown, initially ellipsoidal, hyaline, aseptate, becoming fusiform, 1-3-septate, slightly rounded or pointed at both ends, constricted at the central septum, with large guttules and without a mucilaginous sheath. Asexual morph: Undetermined.

Culture characteristics - Colonies on PDA reaching $30 \mathrm{~mm}$ diameter after 7 days at $25^{\circ} \mathrm{C}$ in the dark, colonies circular, flat, margin wavy, fairly, fluffy appearance in margins, colony from above: light brown and; reverse: pale brown centre and dark brown margin.

Material examined - China, Yunnan Province, Xishuangbanna, dead twigs (attached to the tree) of Magnolia grandiflora (Magnoliaceae), 26 April 2017, N. I. de Silva, NI154 (MFLU 181021 holotype, HKAS100657 isotype), ex-type living culture, MFLUCC 18-0719 = KUMCC 170189. 


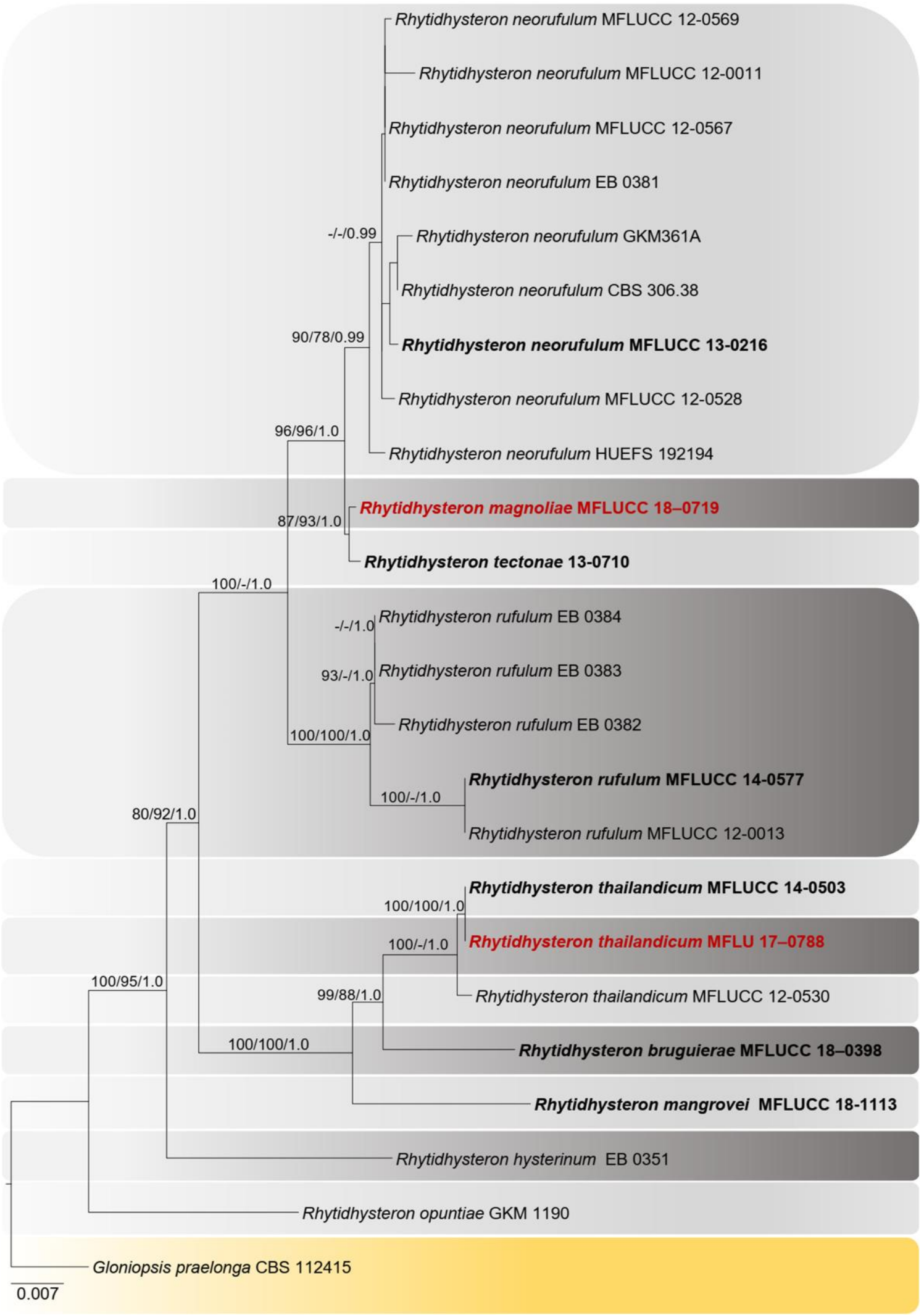

Fig. 1 - Phylogram generated from RAxML based on combined LSU, ITS, SSU and tefl sequence data. Maximum likelihood bootstrap support values (ML), maximum parsimony bootstrap support values (MP) and Bayesian posterior probabilities (PP) are indicated on the nodes as (ML/MP/PP). Bootstrap support values greater than $75 \%$ and Bayesian posterior probabilities greater than 0.90 are indicated at the nodes. The tree is rooted with Gloniopsis praelonga (CBS 112415). The new species and the new record are in red bold. Ex-type strains are in black bold. 
Table 2 Synopsis of Rhytidhysteron magnoliae and related species.

\begin{tabular}{|c|c|c|c|c|c|}
\hline Names & Ascomata & Exciple & Asci & Ascospores & References \\
\hline $\begin{array}{l}R . \\
\text { bruguierae }\end{array}$ & $\begin{array}{l}(400-950 \times \\
548-570) \mu \mathrm{m}, \\
\text { perpendicularly } \\
\text { striate }\end{array}$ & $\begin{array}{l}\text { Dark brown to } \\
\text { black, } \\
\text { thick-walled } \\
\text { cells of } \\
\text { textura } \\
\text { angularis }\end{array}$ & $\begin{array}{l}(128-148 \times 10- \\
14) \mu \mathrm{m}, \\
6-8 \text {-spored }\end{array}$ & $\begin{array}{l}\text { 1-3-septate, } \\
(14-26 \times 6.2-9) \\
\mu \mathrm{m}\end{array}$ & $\begin{array}{l}\text { Dayarathne } \\
\text { et al. (2020) }\end{array}$ \\
\hline $\begin{array}{l}R . \\
\text { brasiliense }\end{array}$ & $\begin{array}{l}(1087-1715 \times 340- \\
447) \mu \mathrm{m}, \text { rough- } \\
\text { without striations }\end{array}$ & Not given & $\begin{array}{l}(230-250 \times 20- \\
30) \mu \mathrm{m}, 8- \\
\text { spored }\end{array}$ & $\begin{array}{l}\text { 1-3-septate, } \\
(40-45 \times 12-20) \\
\mu \mathrm{m}\end{array}$ & $\begin{array}{l}\text { Thambugala } \\
\text { et al. (2016) }\end{array}$ \\
\hline $\begin{array}{l}R . \\
\text { columbiense }\end{array}$ & $\begin{array}{l}(1500-3000 \times \\
1200-1800) \mu \mathrm{m}, \\
\text { boat-shaped, striate, } \\
\text { brown-black disc }\end{array}$ & $\begin{array}{l}\text { Dark brown to } \\
\text { black, thick- } \\
\text { walled cells of } \\
\text { textura } \\
\text { angularis }\end{array}$ & $\begin{array}{l}(175-190 \times 14- \\
18) \mu \mathrm{m}, 6-8- \\
\text { spored }\end{array}$ & $\begin{array}{l}\text { (1-)3-septate, } \\
38-52 \times 13-18 \\
\mu \mathrm{m}\end{array}$ & $\begin{array}{l}\text { Soto \& } \\
\text { Lucking } \\
\text { (2017) }\end{array}$ \\
\hline $\begin{array}{l}R . \\
\text { hysterinum }\end{array}$ & $\begin{array}{l}(1000-3000 \times 500) \\
\mu \mathrm{m}, \text { smooth-striate, } \\
\text { black disc }\end{array}$ & Not given & $\begin{array}{l}\text { (185-220 × 15- } \\
\text { 17) 4-8-spored }\end{array}$ & $\begin{array}{l}\text { 1-septate, } \\
(20-32 \times 12-15) \\
\mu \mathrm{m}\end{array}$ & $\begin{array}{l}\text { Samuels \& } \\
\text { Müller } \\
\text { (1979) }\end{array}$ \\
\hline $\begin{array}{l}R . \\
\text { magnoliae }\end{array}$ & $\begin{array}{l}(1200-2300 \times 540- \\
600) \mu \mathrm{m} \text { elliptic or } \\
\text { irregular shape } \\
\text { ascomata with } \\
\text { distinct striation, } \\
\text { dark brown at the } \\
\text { center }\end{array}$ & $\begin{array}{l}2 \text { layers; black to } \\
\text { dark brown, } \\
\text { thick-walled } \\
\text { cells of textura } \\
\text { angularis outer } \\
\text { layer and } \\
\text { hyaline, thin- } \\
\text { walled, } \\
\text { somewhat } \\
\text { flattened cells of } \\
\text { textura } \\
\text { angularis to } \\
\text { textura } \\
\text { prismatica inner } \\
\text { layer }\end{array}$ & $\begin{array}{l}(176 \times 14) \mu \mathrm{m}, \\
8 \text {-spored }\end{array}$ & $\begin{array}{l}\text { 1-3-septate, } \\
(25-32 \times 8-12) \\
\mu \mathrm{m}\end{array}$ & This study \\
\hline $\begin{array}{l}R . \\
\text { mangrovei }\end{array}$ & $\begin{array}{l}(930-1980 \times 785- \\
91) \mu \mathrm{m}, \text { lenticular } \\
\text { to irregular, rough- } \\
\text { striate, brown-black } \\
\text { disc }\end{array}$ & $\begin{array}{l}\text { Dark brown to } \\
\text { black, thin- } \\
\text { walled cells of } \\
\text { textura } \\
\text { angularis }\end{array}$ & $\begin{array}{l}(146 \times 9.5) \mu \mathrm{m}, \\
(2-6-) 8 \text {-spored }\end{array}$ & $\begin{array}{l}\text { 1-3-septate, } \\
(21-28 \times 7.5-8.5) \\
\mu \mathrm{m}\end{array}$ & $\begin{array}{l}\text { Kumar et al. } \\
(2019)\end{array}$ \\
\hline $\begin{array}{l}R . \\
\text { neorufulum }\end{array}$ & $\begin{array}{l}(835-1800 \times 600- \\
1320) \mu \mathrm{m}, \text { elliptic } \\
\text { or irregular, rough- } \\
\text { without striations, } \\
\text { black or yellow } \\
\text { center }\end{array}$ & $\begin{array}{l}\text { Dark brown to } \\
\text { black, thick- } \\
\text { walled cells of } \\
\text { textura } \\
\text { angularis }\end{array}$ & $\begin{array}{l}(200 \times 10.9) \mu \mathrm{m}, \\
8 \text {-spored }\end{array}$ & $\begin{array}{l}\text { 1-3-septate, } \\
(27-34 \times 6.5- \\
12.5) \mu \mathrm{m}\end{array}$ & $\begin{array}{l}\text { Thambugala } \\
\text { et al. (2016) }\end{array}$ \\
\hline R. rufulum & $\begin{array}{l}(900-2350 \times 1134- \\
1450) \mu \mathrm{m}, \text { elliptic } \\
\text { or irregular, striate, } \\
\text { black or red center }\end{array}$ & $\begin{array}{l}2 \text { layers; outer } \\
\text { layer dark brown } \\
\text { to black, cells of } \\
\text { textura } \\
\text { angularis or } \\
\text { textura globosa, } \\
\text { inner layer of } \\
\text { hyaline cells of } \\
\text { textura } \\
\text { angularis to } \\
\text { textura } \\
\text { prismatica }\end{array}$ & $\begin{array}{l}(202 \times 13.5) \mu \mathrm{m}, \\
8 \text {-spored }\end{array}$ & $\begin{array}{l}\text { 1-3-septate, } \\
(21-36 \times 9-13) \\
\mu \mathrm{m}\end{array}$ & $\begin{array}{l}\text { Thambugala } \\
\text { et al. (2016) }\end{array}$ \\
\hline
\end{tabular}


Table 2 Continued.

\begin{tabular}{|c|c|c|c|c|c|}
\hline Names & Ascomata & Exciple & Asci & Ascospores & References \\
\hline$R$. tectonae & $\begin{array}{l}(1225-3365 \times \\
370-835) \mu \mathrm{m}, \\
\text { striate, yellow } \\
\text { center }\end{array}$ & $\begin{array}{l}2 \text { layers; outer } \\
\text { layer black to } \\
\text { dark reddish, } \\
\text { thick-walled } \\
\text { cells of textura } \\
\text { angularis and } \\
\text { inner layer } \\
\text { hyaline, thin- } \\
\text { walled cells of } \\
\text { textura angularis }\end{array}$ & $\begin{array}{l}(155 \times 13) \mu \mathrm{m}, 8- \\
\text { spored }\end{array}$ & $\begin{array}{l}\text { 1-septate, } \\
(19-31 \times 8-13) \\
\mu \mathrm{m}\end{array}$ & $\begin{array}{l}\text { Doilom et al. } \\
\text { (2017) }\end{array}$ \\
\hline $\begin{array}{l}R . \\
\text { thailandicum }\end{array}$ & $\begin{array}{l}(700-1200 \times 530- \\
750) \mu \mathrm{m}, \text { globose to } \\
\text { subglobose, rough- } \\
\text { without striations }\end{array}$ & $\begin{array}{l}\text { Brown to dark } \\
\text { brown, thick- } \\
\text { walled cells of } \\
\text { textura angularis }\end{array}$ & $\begin{array}{l}(145 \times 12.8) \mu \mathrm{m}, \\
(3-) 6-8 \text {-spored }\end{array}$ & $\begin{array}{l}\text { 3-septate, } \\
(20-31 \times 7.5-12) \\
\mu \mathrm{m}\end{array}$ & $\begin{array}{l}\text { Thambugala } \\
\text { et al. (2016) }\end{array}$ \\
\hline
\end{tabular}

Notes - The morphological features of Rhytidhysteron magnoliae are in accordance with the generic concept of Rhytidhysteron as they have large, conspicuously navicular hysterothecia, which open by a longitudinal slit and become irregularly apothecioid when wet. Ascospores are pigmented, sparsely septate (Boehm et al. 2009b, Thambugala et al. 2016, Soto \& Lucking 2017). In the present multi-gene analyses (LSU, ITS, SSU and tef1), $R$. magnoliae (MFLU 18-1021) nested with other Rhytidhysteron species (Fig. 1), in particular, it was closely related to R. tectonae Doilom \& K.D. Hyde and formed a well- supported clade (87\% ML, 93\% MP, 1.00 BYPP). However, $R$. magnoliae is distinct from $R$. tectonae in having elliptic or irregular ascomata with distinct striations. Further details are given in Table 2.

Rhytidhysteron magnoliae also differs from $R$. tectonae in having slightly larger asci $(176 \times$ $14 \mu \mathrm{m})$ and ascospores $(25-32 \times 8-12 ; \overline{\mathrm{x}}=29 \times 10 \mu \mathrm{m})$, whereas $R$. tectonae has slightly smaller asci $(155 \times 13 \mu \mathrm{m})$ and ascospores $(19-31 \times 8-13 ; \overline{\mathrm{x}}=27 \times 10 \mu \mathrm{m})$. In contrast to $R$. tectonae, $R$. magnoliae initially has ellipsoidal, hyaline ascospores becoming fusiform, pale brown to dark brown when mature with large guttules, whereas $R$. tectonae initially has subglobose, hyaline to pale brown ascospores becoming ellipsoidal to fusiform, pale brown to dark brown when mature and without guttules (Doilom et al. 2017). Rhytidhysteron magnoliae also differs from $R$. tectonae in terms of host association and locality, as the latter has been reported from the dead branches of Tectona grandis in Thailand (Doilom et al. 2017).

Rhytidhysteron thailandicum Thambug. \& K.D. Hyde, Cryptog. Mycol. 37(1): 110 (2016)

Fig. 3

Index Fungorum Number: IF 551866; Facesoffungi number: FoF 01841

Saprobic on decaying wood of Morus australis. Sexual morph: Hysterothecia 750-900 $\mu \mathrm{m}$ long, 480-600 $\mu \mathrm{m}$ high, $600-750 \mu \mathrm{m}$ diameter $(\overline{\mathrm{x}}=850 \times 550 \times 650, \mathrm{n}=5)$, scattered to gregarious, semi immersed to superficial, apothecioid, elongate and depressed, globose to subglobose, dark brown to black, coriaceous, compressed at apex, opening by a longitudinal slit. Exciple $70-110 \mu \mathrm{m}$ wide $(\overline{\mathrm{x}}=95, \mathrm{n}=10)$, composed of dark brown to black, thin-walled cells of textura angularis. Hamathecium comprising 1-2 $\mu \mathrm{m}$ wide, dense, cellular, hyaline, septate, pseudoparaphyses, forming a dark epithecium above asci and enclosed in a gelatinous matrix. Asci 130-160 × 9-14 $\mu \mathrm{m}(\overline{\mathrm{x}}=147 \times 11.5, \mathrm{n}=20), 8$-spored, bitunicate, cylindrical, with short pedicel, rounded at the apex, with an ocular chamber. Ascospores $22-25 \times 9-10 \mu \mathrm{m}(\overline{\mathrm{x}}=23.8 \times 9.3, \mathrm{n}=$ 30 ), uniseriate, hyaline to lightly pigmented when immature, becoming reddish brown to brown when mature, ellipsoidal to fusoid, straight or curved, rounded to slightly pointed at both ends, (1-)3-septate, guttulate, smooth-walled. Asexual morph: Undetermined. 

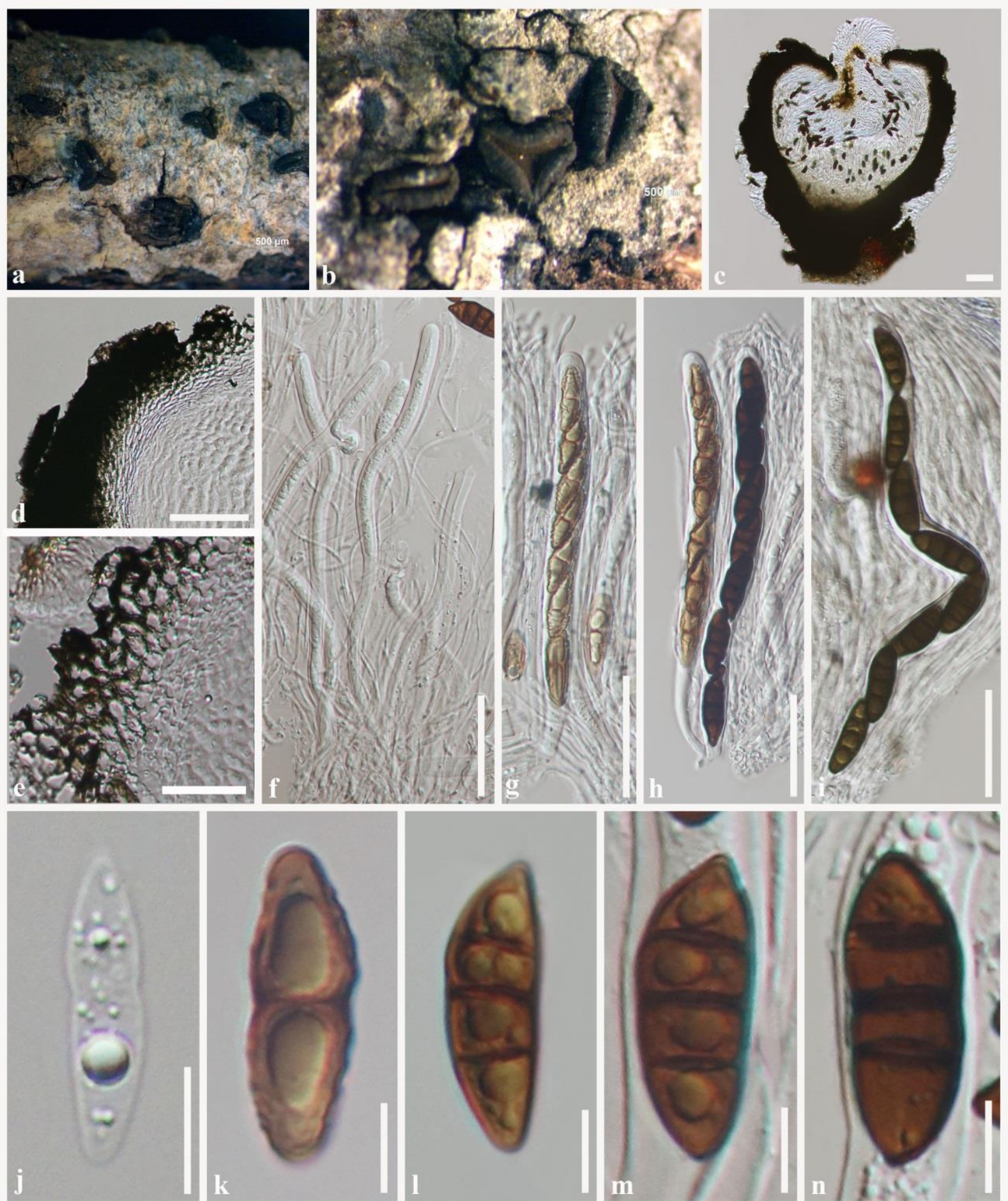

Fig. 2 - Rhytidhysteron magnoliae (MFLU 18-1021, holotype). a, b Appearance of hysterothecia on the host surface. c Vertical section through hysterothecium. d, e Exciple. f Pseudoparaphyses with immature asci. $\mathrm{g}-\mathrm{i}$ Asci. $\mathrm{j}-\mathrm{n}$ Ascospores. Scale bars: $\mathrm{c}=80 \mu \mathrm{m}, \mathrm{d}=50 \mu \mathrm{m}, \mathrm{e}=20 \mu \mathrm{m}, \mathrm{f}-\mathrm{i}=$ $50 \mu \mathrm{m}, \mathrm{j}-\mathrm{n}=10 \mu \mathrm{m}$.

Material examined - China, Taiwan region, Chiayi, Fanlu Township area, Dahu forest, decaying wood of Morus australis Poir. (Moraceae), 18 September 2017, D.S. Tennakoon, SL001 (MFLU 17-0788, new host record).

Notes - Rhytidhysteron thailandicum was introduced by Thambugala et al. (2016) based on both morphology and phylogenetic analyses. As both morphological characteristics and molecular data examined largely overlap with those of $R$. thailandicum (MFLUCC 14-0503), we report our collection (MFLU 17-0788) as a new host record of $R$. thailandicum from decaying wood of Morus 
australis (Moraceae) in Taiwan region of China. Our collection shares similar morphological characteristics with $R$. thailandicum (MFLU 14-0607) in having semi-immersed to superficial, coriaceous, apothecioid hysterothecia, cylindrical, short pedicellate asci and ellipsoidal to fusoid, (1-)3-septate, reddish-brown ascospores (Thambugala et al. 2016, Hyde et al. 2017). According to our combined multi-gene (LSU, ITS, SSU and tefl) phylogenetic analyses, our collection nested together with $R$. thailandicum (MFLUCC 14-0503). This is the first record of $R$. thailandicum on Morus australis.

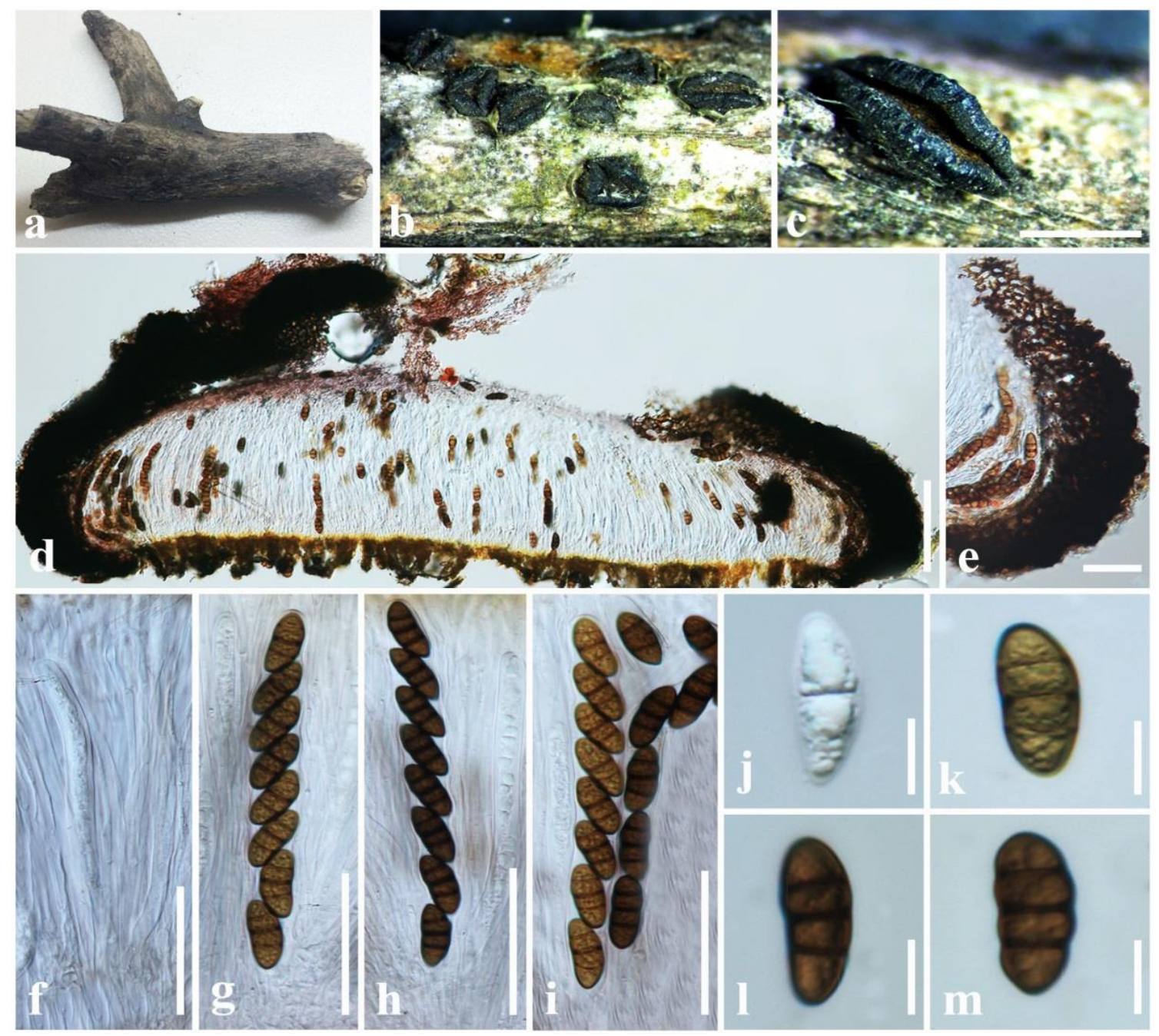

Fig. 3 - Rhytidhysteron thailandicum (MFLU 17-0788, a new host record). a Decaying wood specimen of Morus australis. b Appearance of hysterothecia on the host surface. c Close-up of hysterothecium. d Vertical section through hysterothecium. e Exciple. f Pseudoparaphyses with immature asci. $\mathrm{g}-\mathrm{i}$ Asci. $\mathrm{j}-\mathrm{m}$ Ascospores. Scale bars: $\mathrm{c}=500 \mu \mathrm{m}, \mathrm{d}=200 \mu \mathrm{m}, \mathrm{e}-\mathrm{i}=50 \mu \mathrm{m}, \mathrm{j}-\mathrm{m}=$ $10 \mu \mathrm{m}$.

\section{Discussion}

Hysteriaceous ascomycetes are an interesting group of fungi, mainly occurring on twigs or bark of various woody and herbaceous plants in terrestrial and aquatic environments worldwide. Hysteriaceae is one of the most diverse families in the order Hysteriales. Currently, 13 genera are accepted in Hysteriaceae, viz. Actidiographium Lar.N. Vassiljeva, Gloniella Sacc., Gloniopsis De Not., Hysterium Tode, Hysterobrevium E. Boehm \& C.L. Schoch, Hysterocarina H. Zogg 1949, Hysterodifractum D.A.C. Almeida, Gusmão \& A.N. Mill., Hysteroglonium Rehm ex Lindau, Oedohysterium E. Boehm \& C.L. Schoch, Ostreichnion Duby, Pseudoscypha J. Reid \& Piroz., Psiloglonium Höhn. and Rhytidhysteron (Hongsanan et al. 2020). 
Rhytidhysteron species seem to have a diverse distribution since they have been recorded from both temperate and tropical regions in Australia, Brazil, Colombia, Cuba, India, New Zealand, Taiwan, Thailand and Venezuela (Thambugala et al. 2016, Doilom et al. 2017, Kumar et al. 2019, Farr \& Rossman 2020). This study provides the first geographical records of Rhytidhysteron species in China. Apart from being cosmopolitan, it appears that this genus is phylogenetically highly diverse given that recent studies have revealed a number of new species. For instance, Rhytidhysteron neorufulum Thambug. \& K.D. Hyde and $R$. thailandicum were introduced by Thambugala et al. (2016) and Doilom et al. (2017) introduced $R$. tectonae Doilom \& K.D. Hyde. Subsequently, $R$. columbiense Soto-Medina \& Lücking was introduced by Soto-Medina and Lücking (2017) only based on morphological studies and R. mangrovei Vin. Kumar \& K.D. Hyde was introduced by Kumar et al. (2019), based on morphological studies and molecular data. In this study, we provide morphological characteristics and phylogenetic data for another new species of Rhytidhysteron; $R$. magnoliae collected from Magnolia grandiflora (Magnoliaceae).

The host specificity of Rhytidhysteron species has yet to be studied, despite having been collected from various plant families (i. e. Acanthaceae, Annonaceae, Apocynaceae, Bignoniaceae, Capparaceae, Fabaceae, Lamiaceae, Rutaceae) (Thambugala et al. 2016, Doilom et al. 2017, Kumar et al. 2019, Farr \& Rossman 2020). Interestingly, we found $R$. thailandicum from Morus australis is the first Rhytidhysteron record from the plant family Moraceae. This study incorporates both morphological and multigene phylogenetic approaches (LSU, ITS, SSU and tefl) and provides insights into the taxonomic novelties of the genus Rhytidhysteron. It is also noted that phylogeny recovered herein, agreed with previously established taxa in that Rhytidhysteron should be placed within the Hysteriales (Thambugala et al. 2016, Doilom et al. 2017, Kumar et al. 2019, Dayarathne et al. 2020). The findings of this study expand the Rhytidhysteron taxa up to 22 species. However, only nine Rhytidhysteron species including the new species introduced in the present study have molecular data. Therefore, it is essential to use sequence data for clarifying the phylogenetic affinity of Rhytidhysteron species in future studies (especially for the type species, $R$. brasiliense Speg.). Thus, it is necessary to collect more species of Rhytidhysteron and similar taxa in different geographic regions and hosts, isolate them into cultures, describe their morphology, analyze their DNA sequences and investigate their phylogenetic relationships for better identification and classification.

\section{Acknowledgements}

This work was supported by grants from Chiang Mai University and TRF Research-Team Association Grant (RTA5880006). Samantha C. Karunarathna thanks CAS President's International Fellowship Initiative (PIFI) for funding his postdoctoral research (number 2018PC0006) and National Science Foundation of China (NSFC) for funding his research work under project code 31851110759. We wish to thank the Key Research Program of Frontier Sciences, CAS (grant no. QYZDY-SSWSMC014" and "973 key project of the National Natural Science Foundation of China (grant no. 2014CB954101). Kevin D. Hyde thanks the grant Impact of climate change on fungal diversity and biogeography in the Greater Mekong Subregion (grant no: RDG6130001). Yunnan Provincial Department of Human Resources and Social Security (grant no. Y836181261) and the National Nature Science Foundation of China (NSFC; grant no. 31850410489) are also acknowledged. Germplasm Bank of Wild Species in Southwest China, Kunming Institute of Botany, Chinese Academy of Science, Kunming is thanked for supporting molecular phylogenetic experiments of this study. Dr. Shaun Pennycook is thanked for nomenclatural clarification of the new species.

\section{References}

Ariyawansa HA, Jaklitsch WM, Voglmayr H. 2018 - Additions to Taiwan fungal flora 1: Neomassariaceae fam. nov. Cryptogamie Mycologie 39(3), 359-373. 
Boehm EWA, Schoch CL, Spatafora JW. 2009a - On the evolution of the Hysteriaceae and Mytilinidiaceae (Pleosporomycetidae, Dothideomycetes, Ascomycota) using four nuclear genes. Mycological Research 113, 461-479.

Boehm EWA, Mugambi GK, Miller AN, Huhndorf SM, et al. 2009b - A molecular phylogenetic reappraisal of the Hysteriaceae, Mytilinidiaceae and Gloniaceae (Pleosporomycetidae, Dothideomycetes) with keys to world species. Studies in Mycology 64, 49-83.

Chomnunti P, Hongsanan S, Aguirre-Hudson B, Tian Q et al. 2014 - The sooty moulds. Fungal Diversity 66, 1-36.

Dayarathne MC, Jones EBG, Maharachchikumbura SSN, Devadatha B et al. 2020 - Morphomolecular characterization of microfungi associated with marine based habitats. Mycosphere $11,1-188$.

de Almeida DAC. 2014 - A new genus and three new species of hysteriaceous ascomycetes from the semiarid region of Brazil. Phytotaxa 176(1), 298-308.

Doilom M, Dissanayake AJ, Wanasinghe DN, Boonmee S et al. 2017 - Microfungi on Tectona grandis (teak) in Northern Thailand. Fungal Diversity 82, 107-182.

Farr DF, Rossman AY. 2020 - Fungal databases, Systematic mycology and microbiology laboratory, ARS, USDA, from: http://nt.ars-grin.gov/fungaldatabases (Retrieved on February 10, 2020).

Hongsanan S, Hyde KD, Phookamsak R, Wanasinghe DN et al. 2020 - Refined families of Dothideomycetes. Fungal Diversity (in prep.)

Huelsenbeck JP, Ronqvist F. 2001 - MRBAYES: Bayesian inference of phylogenetic trees. Bioinformatics 17, 754-755.

Hyde KD, Norphanphoun C, Abreu VP, Bazzicalupo A et al. 2017 - Fungal diversity notes 603708: taxonomic and phylogenetic notes on genera and species. Fungal Diversity 87, 1-235.

Hyde KD, Jones EBG, Liu JK, Ariyawansa HA et al. 2013 - Families of Dothideomycetes. Fungal Diversity 63, 1-313.

Index Fungorum. 2020 - Available from: http://www.indexfungorum.org/names/Names.asp (Accessed on January 20, 2020).

Jayasiri SC, Hyde KD, Ariyawansa HA, Bhat J et al. 2015 - The Faces of Fungi database: fungal names linked with morphology, phylogeny and human impacts. Fungal Diversity 74, 3-18.

Jayasiri SC, Hyde KD, Jones EG, Ariyawansae HA et al. 2017 - A new hysteriform dothideomycete (Gloniaceae, Pleosporomycetidae incertae sedis), Purpurepithecium murisporum gen. et sp. nov. on pine cone scales. Cryptogamie, Mycologie, 38(2), 241-251.

Kumar V, Cheewangkoon R, Thambugala KM, Jones GEB et al. 2019 - Rhytidhysteron mangrovei (Hysteriaceae), a new species from mangroves in Phetchaburi Province, Thailand, Phytotaxa 401 (3), 166-178.

Liu JK, Hyde KD, Jeewon R, Phillips AJ et al. 2017 - Ranking higher taxa using divergence times: a case study in Dothideomycetes. Fungal Diversity 84(1), 75-99.

Posada D, Crandall KA. 1998 - Modeltest: testing the model of DNA substitution. Bioinformatics $14,817-818$.

Rambaut A, Drummond A. 2008 - FigTree: Tree figure drawing tool, version 1.2. 2. Institute of Evolutionary Biology, University of Edinburgh.

Rehner SA. 2001 - Primers for Elongation Factor 1-alpha (EF1-alpha). http://ocid.nacse.org/research/deephyphae/EF1primer.pdf

Samuels GJ, Muller E. 1979 - Life history studies of Brazilian ascomycetes. 7. Rhytidhysteron rufulum and the genus Eutryblidiella. Sydowia 32, 277-292.

Silvestro D, Michalak I. 2012 - raxmlGUI: a graphical front-end for RAxML. Organisms Diversity and Evolution 12, 335-337.

Soto EM, Lücking R. 2017 - A new species of Rhytidhysteron (Ascomycota: Patellariaceae) from Colombia, with a provisional working key to known species in the world Artículo original. Revista de la Academia Colombiana de Ciencias Exactas, Físicas y Naturales 41, 59-63. 
Swofford DL. 2002 - PAUP: phylogenetic analysis using parsimony, version 4.0 b10. Sinauer Associates, Sunderland.

Thambugala KM, Hyde KD, Eungwanichayapant PD, Romero AI et al. 2016 - Additions to the Genus Rhytidhysteron in Hysteriaceae. Cryptogamie Mycologie 37, 99-116.

Vilgalys R, Hester M. 1990 - Rapid genetic identification and mapping of enzymatically amplified ribosomal DNA from several Cryptococcus species. Journal of Bacteriology 172, 4238-4246.

White TJ, Bruns T, Lee S, Taylor J. 1990 - Amplification and direct sequencing of fungal ribosomal RNA genes for phylogenetics. In: InnisMA,Gelfand DH, Sninsky JJ, White TJ (eds) PCR protocols: a guide to methods and applications. Academic, San Diego, 315-322.

Wijayawardene NN, Hyde KD, Rajeshkumar, KC, Hawksworth DL et al. 2017 - Outline of Ascomycota: 2017 Fungal Diversity 86, 1-594.

Wijayawardene N, Hyde KD, Lumbsch T, Liu JK et al. 2018 - Outline of Ascomycota. Fungal Diversity 88, 1560-2745. 